\title{
International Heart Valve Bank Survey: A Review of Processing Practices and Activity Outcomes
}

\author{
Wee Ling Heng, ${ }^{1}$ Helmi Albrecht, ${ }^{2}$ Paul Chiappini, ${ }^{3}$ \\ Yeong Phang Lim, ${ }^{1}$ and Linda Manning ${ }^{3}$ \\ ${ }^{1}$ National Cardiovascular Homograft Bank, Department of Cardiothoracic Surgery, \\ National Heart Centre Singapore, Singapore 168752 \\ ${ }^{2}$ Sydney Heart Valve Bank, St. Vincent's Hospital, 390 Victoria Street, Darlinghurst, NSW 2010, Australia \\ ${ }^{3}$ Cell and Tissue Therapies WA, Royal Perth Hospital, 197 Wellington Street, Perth, WA 6000, Australia \\ Correspondence should be addressed to Wee Ling Heng; heng.wee.ling@nhcs.com.sg
}

Received 19 June 2013; Revised 13 August 2013; Accepted 13 August 2013

Academic Editor: F. H. J. Claas

Copyright (c) 2013 Wee Ling Heng et al. This is an open access article distributed under the Creative Commons Attribution License, which permits unrestricted use, distribution, and reproduction in any medium, provided the original work is properly cited.

\begin{abstract}
A survey of 24 international heart valve banks was conducted to acquire information on heart valve processing techniques used and outcomes achieved. The objective was to provide an overview of heart valve banking activities for tissue bankers, tissue banking associations, and regulatory bodies worldwide. Despite similarities found for basic manufacturing processes, distinct differences in procedural details were also identified. The similarities included (1) use of sterile culture media for procedures, (2) antibiotic decontamination, (3) use of dimethyl sulfoxide (DMSO) as a cryoprotectant, (4) controlled rate freezing for cryopreservation, and (5) storage at ultralow temperatures of below $-135^{\circ} \mathrm{C}$. Differences in procedures included (1) type of sterile media used, (2) antibiotics combination, (3) temperature and duration used for bioburden reduction, (4) concentration of DMSO used for cryopreservation, and (5) storage duration for released allografts. For most banks, the primary reasons why allografts failed to meet release criteria were positive microbiological culture and abnormal morphology. On average, $85 \%$ of allografts meeting release criteria were implanted, with valve size and type being the main reasons why released allografts were not used clinically. The wide variation in percentage of allografts meeting release requirements, despite undergoing validated manufacturing procedures, justifies the need for regular review of important outcomes as cited in this paper, in order to encourage comparison and improvements in the HVBs' processes.
\end{abstract}

\section{Introduction}

Since the first heart valve bank (HVB) started in New Zealand in 1962 , the recovery, processing, and storage techniques have been constantly evolving to improve the quality and safety of cardiovascular allografts for clinical implantation. During the initial era of allograft usage, fresh aseptically recovered allografts were implanted within hours or days of recovery. This was followed by aggressive decontamination methods, such as gamma-irradiation and chemical sterilisation using formaldehyde, glutaraldehyde, beta-propiolactone, and ethylene oxide. Coupled with harsh preservation techniques of freeze-drying and flash-freezing in liquid nitrogen, these "sterilised" tissues rapidly failed in situ due to high incidence of leaflet degeneration, cusp rupture, and/or loss of durability and hemodynamic function. For these reasons, allograft use was discontinued until newer preservation methods were developed. Eventually, "sterilised" tissues were replaced by aseptically recovered ones treated with antibiotics and stored in culture media at $4^{\circ} \mathrm{C}$ for up to 6 weeks. These milder techniques improved valve durability and, ultimately, patient outcome. Today, the majority of HVBs worldwide use aseptic retrieval of donor heart valves followed by low-dose antibiotic decontamination, cryopreservation, and storage at ultralow temperature until the valves are required for implantation [1$3]$.

Regulatory bodies throughout the world promote global harmonisation of manufacturing procedures as a mean to standardise product quality and safety and to simplify the exchange of "like" products between jurisdictions. Although 
TABLE 1: Summary of heart valve processing protocols used by HVBs in Europe.

\begin{tabular}{|c|c|c|c|c|c|}
\hline $\begin{array}{l}\text { Bank } \\
\text { number }\end{array}$ & Processing media & Antibiotic regimen & $\begin{array}{l}\text { Incubation } \\
\text { protocol }\end{array}$ & $\begin{array}{l}\text { Cryopreservation } \\
\text { method }\end{array}$ & $\begin{array}{l}\text { Storage condition } \\
\text { and duration }\end{array}$ \\
\hline E1 & $\begin{array}{l}\text { Until 2004: M199 } \\
2004 \text { onwards: RPMI-1640 }\end{array}$ & $\begin{array}{l}\text { Vancomycin: } 500 \mathrm{ug} / \mathrm{mL} \\
\text { Gentamycin: } 50 \mathrm{ug} / \mathrm{mL} \\
\text { Piperacillin: } 500 \mathrm{ug} / \mathrm{mL} \\
\text { Nystatin: } 2500 \mathrm{U} / \mathrm{mL}\end{array}$ & $\begin{array}{l}\text { Room } \\
\text { temperature, } 24 \\
\text { hours, in the dark }\end{array}$ & $\begin{array}{l}\text { Controlled rate } \\
\text { freezing }\end{array}$ & $\begin{array}{l}\text { Liquid nitrogen } \\
\text { vapour phase: } 5 \\
\text { years }\end{array}$ \\
\hline E2 & $\begin{array}{l}\text { RPMI-1640 with glutamine } \\
\text { Addition of } 20 \% \text { human } \\
\text { albumin and DMSO for } \\
\text { cryopreservation and } \\
\text { storage }\end{array}$ & $\begin{array}{l}\text { Cefoxitin: } 240 \mathrm{ug} / \mathrm{mL} \\
\text { Lincomycin: } 120 \mathrm{ug} / \mathrm{mL} \\
\text { Colimycin: } 100 \mathrm{ug} / \mathrm{mL} \\
\text { Vancomycin: } 50 \mathrm{ug} / \mathrm{mL}\end{array}$ & $4^{\circ} \mathrm{C}, 24$ hours & $\begin{array}{l}\text { Controlled rate } \\
\text { freezing from } \\
+10^{\circ} \mathrm{C} \text { to }-110^{\circ} \mathrm{C}\end{array}$ & $\begin{array}{l}\text { Liquid nitrogen } \\
\text { vapour phase: } 5 \\
\text { years }\end{array}$ \\
\hline E3 & $\begin{array}{l}\text { Transport solution: } \\
\text { TRIS buffered isotonic } \\
\text { saline } \\
\text { Antibiotics media: M199 } \\
\text { Cryopreservation media: } \\
\text { HBSS with } 25 \text { mM HEPES } \\
+20 \% \text { DMSO }\end{array}$ & $\begin{array}{l}\text { Gentamicin: } 4000 \mathrm{ug} / \mathrm{mL} \\
\text { Imipenem: } 200 \mathrm{ug} / \mathrm{mL} \\
\text { Nystatin: } 2500 \mathrm{U} / \mathrm{mL} \\
\text { Polymyxin B: } 200 \mathrm{ug} / \mathrm{mL} \\
\text { Vancomycin: } 50 \mathrm{ug} / \mathrm{mL}\end{array}$ & $2-8^{\circ} \mathrm{C}, 18-24$ hours & $\begin{array}{l}\text { Controlled rate } \\
\text { freezing (at } \\
\left.-1^{\circ} \mathrm{C} / \mathrm{min}\right)\end{array}$ & $-135^{\circ} \mathrm{C}: 10$ years \\
\hline $\mathrm{E} 4$ & $\begin{array}{l}\text { Cryopreservation media: } \\
\text { HBSS with } 25 \text { mM HEPES } \\
+10 \% \text { DMSO }\end{array}$ & $\begin{array}{l}\text { Vancomycin: } 50 \mathrm{ug} / \mathrm{mL} \\
\text { Gentamicin: } 4000 \mathrm{ug} / \mathrm{mL} \\
\text { Ciprofloxacin: } 200 \mathrm{ug} / \mathrm{mL} \\
\text { Amphotericin B: } 50 \mathrm{ug} / \mathrm{mL}\end{array}$ & $\begin{array}{l}\text { Room temperature } \\
\left(21^{\circ} \mathrm{C}\right), 24 \text { hours }\end{array}$ & $\begin{array}{l}\text { Controlled rate } \\
\text { freezing }\end{array}$ & $\begin{array}{l}\text { Liquid nitrogen } \\
\text { vapour phase: } 10 \\
\text { years }\end{array}$ \\
\hline E5 & $\begin{array}{l}\text { Antibiotics media: } \\
\text { RPMI-1640 } \\
\text { Cryopreservation media: } \\
\text { RPMI-1640 + 10\% DMSO }\end{array}$ & $\begin{array}{l}\text { Metronidazol: } 50 \mathrm{ug} / \mathrm{mL} \\
\text { Vancomycin: } 50 \mathrm{ug} / \mathrm{mL} \\
\text { Amikacin: } 50 \mathrm{ug} / \mathrm{mL} \\
\text { Amphotericin B: } 5 \mathrm{ug} / \mathrm{mL}\end{array}$ & $4^{\circ} \mathrm{C}, 24$ hours & $\begin{array}{l}\text { Controlled rate } \\
\text { freezing }\end{array}$ & $\begin{array}{l}\text { Liquid nitrogen } \\
\text { vapour phase: } 15 \\
\text { years }\end{array}$ \\
\hline E6 & $\begin{array}{l}\text { Cryopreservation media: } \\
70 \% \text { TC- } 199+10 \% \text { DMSO } \\
+20 \% \text { human albumin }\end{array}$ & $\begin{array}{l}\text { Vancomycin: } 50 \mathrm{ug} / \mathrm{mL} \\
\text { Tobramycin: } 50 \mathrm{ug} / \mathrm{mL} \\
\text { Cotrimoxazole: } 50 \mathrm{ug} / \mathrm{mL}\end{array}$ & $4^{\circ} \mathrm{C}, 6-24$ hours & $\begin{array}{l}\text { Controlled rate } \\
\text { freezing (at } \\
\left.-1^{\circ} \mathrm{C} / \mathrm{min}\right)\end{array}$ & $\begin{array}{l}\text { Liquid nitrogen } \\
\text { vapour phase: } 10 \\
\text { years }\end{array}$ \\
\hline E7 & $\begin{array}{l}\text { Cryopreservation media: } \\
\text { M199 in the past, use } \\
\text { sodium chloride solution + } \\
10 \% \text { DMSO at present }\end{array}$ & $\begin{array}{l}\text { Fluconazole: } 200 \mathrm{mg} \\
\text { Cefotaxime: } 1 \mathrm{~g}\end{array}$ & $4^{\circ} \mathrm{C}, 24$ hours & $\begin{array}{l}\text { Liquid nitrogen } \\
\text { vapour phase }\end{array}$ & $\begin{array}{l}\text { Liquid nitrogen } \\
\text { vapour phase: } \\
2 \text { years }\end{array}$ \\
\hline E8 & $\begin{array}{l}\text { Antibiotic media: } \\
0.9 \% \text { sodium chloride } \\
\text { Cryopreservation media: } \\
\text { RPMI- } 1640+10 \% \\
\text { cryoprotectant }\end{array}$ & $\begin{array}{l}\text { Metronidazole: } 20 \mathrm{ug} / \mathrm{mL} \\
\text { Gentamicin: } 20 \mathrm{ug} / \mathrm{mL} \\
\text { Flucloxacillin: } 20 \mathrm{ug} / \mathrm{mL}\end{array}$ & $\begin{array}{l}4^{\circ} \mathrm{C} \text {, at a minimum } \\
\text { of } 12 \text { hours }\end{array}$ & $\begin{array}{l}\text { Controlled rate } \\
\text { freezing (down to } \\
\left.-180^{\circ} \mathrm{C}\right)\end{array}$ & $\begin{array}{l}\text { Liquid nitrogen } \\
\text { vapour phase: } 5 \\
\text { years }\end{array}$ \\
\hline E9 & $\begin{array}{l}\text { M199 with Hanks' salts, } \\
\text { L-glutamine, } 25 \mathrm{mM} \\
\text { HEPES }\end{array}$ & $\begin{array}{l}\text { Lincomycin, } \\
\text { polymyxin B sulphate, } \\
\text { vancomycin }\end{array}$ & $4^{\circ} \mathrm{C}, 48$ hours & $\begin{array}{l}\text { No response } \\
\text { provided }\end{array}$ & $\begin{array}{l}\text { Liquid nitrogen } \\
\text { vapour phase: } 5 \\
\text { years }\end{array}$ \\
\hline E10 & $\begin{array}{l}\text { M199 } \\
\text { Antibiotics media: } 200 \mathrm{~mL} \\
\text { of Earles salt in M199 }\end{array}$ & $\begin{array}{l}\text { Amphotericin B: } \\
250 \mathrm{ug} / \mathrm{mL} \\
\text { Fungoral: } 100 \mathrm{ug} / \mathrm{mL} \\
\text { Colistin: } 200 \mathrm{ug} / \mathrm{mL} \\
\text { Vancocin: } 500 \mathrm{ug} / \mathrm{mL} \\
\text { Garamycin: } 530 \mathrm{ug} / \mathrm{mL}\end{array}$ & $4^{\circ} \mathrm{C}-8^{\circ} \mathrm{C}, 24$ hours & $\begin{array}{l}\text { Controlled rate } \\
\text { freezing }\end{array}$ & $\begin{array}{l}\text { Liquid nitrogen } \\
\text { vapour phase: } 10 \\
\text { years }\end{array}$ \\
\hline E11 & $\begin{array}{l}\text { Transport solution: Ringer's } \\
\text { lactate or cardioplegia } \\
\text { solution } \\
\text { Antibiotic media: M199 } \\
\text { Cryopreservation media: } \\
\text { M199 + Antibiotics + 12.5\% } \\
\text { DMSO }\end{array}$ & $\begin{array}{l}\text { Cefuroxime: } 250 \mathrm{ug} / \mathrm{mL} \\
\text { Gentamicin: } 80 \mathrm{ug} / \mathrm{mL} \\
\text { Ciprofloxacin: } 200 \mathrm{ug} / \mathrm{mL} \\
\text { Vancomycin: } 500 \mathrm{ug} / \mathrm{mL} \\
\text { Colistin: } 1000 \mathrm{IU} / \mathrm{mL} \\
\text { Amphotericin B: } 20 \mathrm{ug} / \mathrm{mL}\end{array}$ & $37^{\circ} \mathrm{C}, 18-24$ hours & $\begin{array}{l}\text { Controlled rate } \\
\text { freezing (from } \\
+4^{\circ} \mathrm{C} \text { to }-60^{\circ} \mathrm{C} \text { at } \\
1^{\circ} \mathrm{C} \text { per min; then } \\
\text { transfer to ultralow } \\
\text { temperature } \\
\text { freezer at }-140^{\circ} \mathrm{C} \text { ) } \\
\end{array}$ & $\begin{array}{l}\text { Ultralow } \\
\text { temperature } \\
\left(-140^{\circ} \mathrm{C}\right): 5 \text { years } \\
\text { or }-80^{\circ} \mathrm{C} \text { : for up to } \\
6 \text { months }\end{array}$ \\
\hline
\end{tabular}


TABLE 2: Summary of heart valve processing protocols used by HVBs in North America.

\begin{tabular}{|c|c|c|c|c|c|}
\hline $\begin{array}{l}\text { Bank } \\
\text { number }\end{array}$ & Processing media & Antibiotic regimen & $\begin{array}{l}\text { Incubation } \\
\text { protocol }\end{array}$ & $\begin{array}{l}\text { Cryopreservation } \\
\text { method }\end{array}$ & $\begin{array}{l}\text { Storage condition } \\
\text { and duration }\end{array}$ \\
\hline N1 & $\begin{array}{l}\text { Heart recovery, transport, and } \\
\text { dissection solution: } \\
\text { Ringer's lactate } \\
\text { Antibiotics media: DMEM with } \\
\text { Hepes } \\
\text { Cryopreservation media: } \\
\text { DMEM + 7.5\% DMSO }\end{array}$ & $\begin{array}{l}\text { Vancomycin: } 50 \mathrm{ug} / \mathrm{mL} \\
\text { Gentamicin: } 80 \mathrm{ug} / \mathrm{mL} \\
\text { Cefoxitin: } 240 \mathrm{ug} / \mathrm{mL}\end{array}$ & $\begin{array}{l}\text { Until the } 28 \text { th of } \\
\text { June } 2010 \text { : } \\
1^{\circ} \mathrm{C}-10^{\circ} \mathrm{C}, 22-26 \\
\text { hours } \\
\text { Present: } \\
33^{\circ} \mathrm{C}-38^{\circ} \mathrm{C}, 18-26 \\
\text { hours }\end{array}$ & $\begin{array}{l}\text { Controlled rate } \\
\text { freezing }\end{array}$ & $\begin{array}{l}\text { No response } \\
\text { provided }\end{array}$ \\
\hline $\mathrm{N} 2$ & $\begin{array}{l}\text { Antibiotics media: RPMI-1640 } \\
\text { Cryopreservation media: } \\
\text { X-VIVO-10 + DMSO }\end{array}$ & $\begin{array}{l}\text { Cefoxitin, } \\
\text { colymycin-M, } \\
\text { vancomycin, } \\
\text { lincomycin }\end{array}$ & $4^{\circ} \mathrm{C}, 24$ hours & $\begin{array}{l}\text { Controlled rate } \\
\text { freezing }\end{array}$ & $\begin{array}{l}\text { Liquid nitrogen } \\
\text { vapour phase: } 5 \\
\text { years }\end{array}$ \\
\hline N3 & $\begin{array}{l}\text { Transport and storage solution: } \\
\text { Hanks solution } \\
\text { Dissection solution: saline } \\
\text { Cryopreservation media: } \\
\text { 10\% DMSO }\end{array}$ & $\begin{array}{l}\text { Gentamicin: } 80 \mathrm{mg} / \mathrm{mL} \\
\text { Cefazolin or Kefzol: } \\
1 \mathrm{mg} / \mathrm{mL}\end{array}$ & $4^{\circ} \mathrm{C}, 24$ hours & $\begin{array}{l}\text { Controlled rate } \\
\text { freezing }\end{array}$ & $\begin{array}{l}\text { Ultralow } \\
\text { temperature } \\
\left(-140^{\circ} \mathrm{C}\right): 5 \text { years }\end{array}$ \\
\hline $\mathrm{N} 4$ & $\begin{array}{l}\text { Transport and processing } \\
\text { solution: Ringer's lactate } \\
\text { Cryopreservation media: saline + } \\
\text { RPMI-1640 + RPMI } 1640 \text { with } \\
\text { 10\% FBS + DMSO }\end{array}$ & $\begin{array}{l}\text { Cefoxitin: } 240 \mathrm{ug} / \mathrm{mL} \\
\text { Polymyxin B: } 100 \mathrm{mg} / \mathrm{mL} \\
\text { Vancomycin: } 50 \mathrm{ug} / \mathrm{mL} \\
\text { Lincomycin: } 120 \mathrm{ug} / \mathrm{mL} \\
\text { (soon to use gentamicin) }\end{array}$ & $\begin{array}{l}1^{\circ} \mathrm{C}-10^{\circ} \mathrm{C}, 22-26 \\
\text { hours }\end{array}$ & $\begin{array}{l}\text { Controlled rate } \\
\text { freezing }\end{array}$ & $\begin{array}{l}\text { Liquid nitrogen } \\
\text { vapour phase: } 5 \\
\text { years }\end{array}$ \\
\hline N5 & $\begin{array}{l}\text { DMEM } \\
\text { Cryopreservation media: } \\
\text { cardiac tissue-DMEM + } \\
\text { DMSO + FBS } \\
\text { vascular tissue-DMEM + } \\
\text { DMSO + chondroitin + FBS }\end{array}$ & $\begin{array}{l}\text { Two-stage process: } \\
\text { 1st cocktail to achieve } \\
\text { primary decontamination, } \\
\text { 2nd cocktail to support } \\
\text { tissue }\end{array}$ & $\begin{array}{l}\text { Warm solutions, } \\
>24 \text { hours }\end{array}$ & $\begin{array}{l}\text { Controlled rate } \\
\text { freezing }\end{array}$ & $\begin{array}{l}\text { Liquid nitrogen } \\
\text { vapour phase: } 5 \\
\text { years }\end{array}$ \\
\hline N6 & RPMI-1640 & $\begin{array}{l}\text { Vancomycin: } 50 \mathrm{ug} / \mathrm{mL} \\
\text { Colymycin M: } 75 \mathrm{mg} / \mathrm{mL} \\
\text { Cefoxitin: } 100 \mathrm{mg} / \mathrm{mL} \\
\text { Lincomycin: } 300 \mathrm{mg} / \mathrm{mL}\end{array}$ & $4^{\circ} \mathrm{C}, 24 \pm 2$ hours & $\begin{array}{l}\text { Controlled rate } \\
\text { freezing }\end{array}$ & $\begin{array}{l}\text { Liquid nitrogen } \\
\text { vapour phase: } 5 \\
\text { years }\end{array}$ \\
\hline
\end{tabular}

standardisation is a rational approach for many processes, genuine differences and restrictions in manufacturing circumstances, such as differences in endemic microbial contaminants and patented processes, may limit the extent to which standardisation can be achieved. In addition, as changes to critical processes require validation, which can be both costly and time consuming, any proposed change must be justified in terms of risks and cost benefits for the $\mathrm{HVB}$ and the recipient. As a result, even though tissue banking associations and regulatory bodies governing HVBs worldwide promote similar quality and safety standards for allografts, differences in processing procedures used to achieve these outcomes continue to exist. Essentially, all HVBs follow standards developed by their regional tissue banking associations, which are designed to meet regulatory requirements of their jurisdiction. For instance, in North America, most HVBs follow the standards of the American Association of Tissue Banks (AATB). The European Association of Tissue Banks (EATB), British Association for Tissue Banking (BATB), Associación Español de Bancos de Tejidos (AEBT), and the Spanish Association of Tissue Banks (SATB) have published tissue banking standards for
European banks [4]. In Australia, the Australasian Tissue and Biotherapeutics Forum (ATBF) has developed standards that align with the Therapeutic Goods Administration's (TGA) new Biologicals Regulatory Framework. In Asia, the AsiaPacific Association of Surgical Tissue Banking (APASTB) was formed to encourage tissue-focused research and to promote scientific and social interaction among its members. In all cases, the standards developed by these tissue-banking associations stipulate donor suitability criteria, aseptic processing procedures, and controlled storage requirements of transplantable human tissues, with the common objective of assuring that recipients receive disease- and contaminantfree allografts that fulfil optimum clinical performance [2].

In February 2011, a survey of 24 HVBs in North America, Europe, Australasia, and South Africa was initiated by coauthor Linda Manning. The survey was designed to collate data on heart valve processing procedures and outcomes to inform HVBs and their regulatory bodies on the similarities and differences in heart valve manufacturing activities worldwide. This information was subsequently compiled and presented at the ATBF's 12th Annual Scientific and Business meeting held in Melbourne, Australia, in May 2011 and the AATB's 
TABLE 3: Summary of heart valve processing protocols used by HVBs in Australasia and South Africa.

\begin{tabular}{|c|c|c|c|c|c|}
\hline $\begin{array}{l}\text { Bank } \\
\text { number }\end{array}$ & Processing media & Antibiotic regimen & Incubation protocol & $\begin{array}{l}\text { Cryopreservation } \\
\text { method }\end{array}$ & $\begin{array}{l}\text { Storage condition } \\
\text { and duration }\end{array}$ \\
\hline A1 & $\begin{array}{l}\text { Heart collection, transport, } \\
\text { dissection solution: } \\
\text { Hartmann solution } \\
\text { Antibiotic media: M199 } \\
\text { Cryopreservation media: } \\
\text { M199 + 10\% DMSO }\end{array}$ & $\begin{array}{l}\text { Amoxicillin: } 20 \mathrm{ug} / \mathrm{mL} \\
\text { Gentamicin: } 20 \mathrm{ug} / \mathrm{mL}\end{array}$ & $\begin{array}{l}37^{\circ} \mathrm{C}, 6-8 \text { hours or } \\
4^{\circ} \mathrm{C}, 18-24 \text { hours }\end{array}$ & $\begin{array}{l}\text { Controlled rate } \\
\text { freezing }\end{array}$ & $\begin{array}{l}\text { Liquid nitrogen } \\
\text { vapour phase: } 5 \\
\text { years }\end{array}$ \\
\hline A2 & $\begin{array}{l}\text { Heart collection, transport, } \\
\text { dissection solution: } \\
\text { saline or M199 } \\
\text { Antibiotic media: M199 } \\
\text { Cryopreservation media: } \\
\text { M199 + 10\% DMSO }\end{array}$ & $\begin{array}{l}\text { Penicillin: } 50 \mathrm{IU} / \mathrm{mL} \\
\text { Streptomycin: } 50 \mathrm{ug} / \mathrm{mL}\end{array}$ & $35^{\circ} \mathrm{C}, 6-8$ hours & $\begin{array}{l}\text { Controlled rate } \\
\text { freezing (back up: } \\
\text { manual controlled } \\
\text { rate freezing) }\end{array}$ & $\begin{array}{l}\text { Liquid nitrogen } \\
\text { vapour phase: } 5 \\
\text { years }\end{array}$ \\
\hline A3 & $\begin{array}{l}\text { Heart collection, transport, } \\
\text { dissection solution: } \\
\text { DCD/multiorgan donors/live } \\
\text { donors-saline } \\
\text { Cadaveric-saline or M199 with } \\
\text { antibiotics } \\
\text { Cryopreservation media: } \\
\text { M199 + 10\% DMSO }\end{array}$ & $\begin{array}{l}\text { Penicillin: } 50 \mathrm{IU} / \mathrm{mL} \\
\text { Streptomycin: } 50 \mathrm{ug} / \mathrm{mL}\end{array}$ & $37^{\circ} \mathrm{C}, 6-12$ hours & $\begin{array}{l}\text { Controlled rate } \\
\text { freezing }\end{array}$ & $\begin{array}{l}\text { Liquid nitrogen } \\
\text { vapour phase: } 10 \\
\text { years }\end{array}$ \\
\hline $\mathrm{A} 4$ & $\begin{array}{l}\text { Heart collection, transport, } \\
\text { dissection solution: } \\
\text { Hartmann solution } \\
\text { Antibiotic media: M199 } \\
\text { Cryopreservation media: } \\
\text { M199 + 10\% DMSO }\end{array}$ & $\begin{array}{l}\text { Benzylpenicillin: } 30 \mathrm{ug} / \mathrm{mL} \\
\text { Gentamicin: } 18 \mathrm{ug} / \mathrm{mL}\end{array}$ & $37^{\circ} \mathrm{C}, 6$ hours & $\begin{array}{l}\text { Controlled rate } \\
\text { freezing }\end{array}$ & $\begin{array}{l}\text { Liquid nitrogen } \\
\text { vapour phase: } 5 \\
\text { years }\end{array}$ \\
\hline A5 & $\begin{array}{l}\text { Heart collection, transport, } \\
\text { dissection, rinse solution: } \\
\text { HBSS (preferred) or saline } \\
\text { Antibiotic media: HBSS } \\
\text { Cryopreservation media: } \\
\text { Until Jan 2010-M199 + 10\% } \\
\text { DMSO } \\
\text { After Jan 2010-HBSS + 10\% } \\
\text { DMSO }\end{array}$ & $\begin{array}{l}\text { Cefoxitin: } 240 \mathrm{ug} / \mathrm{mL} \\
\text { Lincomycin: } 120 \mathrm{ug} / \mathrm{mL} \\
\text { Polymyxin B: } 100 \mathrm{ug} / \mathrm{mL} \\
\text { Vancomycin: } 50 \mathrm{ug} / \mathrm{mL} \\
\text { Amphotericin B: } 25 \mathrm{ug} / \mathrm{mL}\end{array}$ & $\begin{array}{l}\text { First soak: } 4^{\circ} \mathrm{C}, 24 \\
\text { hours; } \\
\text { 2nd soak: } 4^{\circ} \mathrm{C}, 24 \\
\text { hours; } \\
\text { transfer to HBSS at } \\
4^{\circ} \mathrm{C} \text { until frozen }\end{array}$ & $\begin{array}{l}\text { Freezing in liquid } \\
\text { nitrogen } \\
\text { vapour-no } \\
\text { controlled rate } \\
\text { equipment used }\end{array}$ & $\begin{array}{l}\text { Liquid nitrogen } \\
\text { vapour phase: } 5 \\
\text { years }\end{array}$ \\
\hline A6 & $\begin{array}{l}\text { Transport, dissection, incubation } \\
\text { solution: M199 } \\
\text { Cryopreservation media: } \\
\text { M199 + 100\% DMSO diluted to } \\
10 \%\end{array}$ & $\begin{array}{l}\text { Vancomycin: } 50 \mathrm{ug} / \mathrm{mL} \\
\text { Amikacin: } 100 \mathrm{ug} / \mathrm{mL}\end{array}$ & $4^{\circ} \mathrm{C}, 24$ hours & $\begin{array}{l}\text { Controlled rate } \\
\text { freezing }\end{array}$ & $\begin{array}{l}\text { Liquid nitrogen } \\
\text { vapour phase: } 5 \\
\text { years }\end{array}$ \\
\hline A7 & $\begin{array}{l}\text { M199 } \\
11 \% \text { DMSO }\end{array}$ & $\begin{array}{l}\text { Mefoxin: } 50 \mathrm{ug} / \mathrm{mL} \\
\text { Piperacillin: } 50 \mathrm{ug} / \mathrm{mL} \\
\text { Amikacin: } 25 \mathrm{ug} / \mathrm{mL} \\
\text { Amphotericin B: } 2.5 \mathrm{ug} / \mathrm{mL}\end{array}$ & $4^{\circ} \mathrm{C}, 12-18$ hours & $\begin{array}{l}\text { Controlled rate } \\
\text { freezing }\end{array}$ & $\begin{array}{l}\text { Liquid nitrogen } \\
\text { vapour phase: } 5-8 \\
\text { years }\end{array}$ \\
\hline
\end{tabular}

35th Annual Meeting held in Arizona, USA, in September 2011. This paper reports the comprehensive data collected from individual HVBs as part of this survey.

\section{Materials and Methods}

The original survey was distributed by electronic mail to 24 HVBs in North America, Europe, Australia, New Zealand, Asia, and South Africa. They were asked to provide information to the following questions, which addressed two aspects.
(1) Allograft processing and storage procedures:

(i) what processing media does your bank use?

(ii) what antibiotic regimen does your bank use?

(iii) what cryopreservation method does your bank use?

(iv) did your bank conduct a formal validation on the media, antibiotics, and antibiotic incubation protocols that you use?

(v) what storage conditions and duration does your bank use for allografts meeting release criteria? 
TABLE 4: Types and concentrations of antibiotics used for decontamination of allografts.

\begin{tabular}{lcc}
\hline Antibiotics/antifungals & Concentration/mL & $\begin{array}{c}\text { Number } \\
\text { of HVBs }\end{array}$ \\
\hline Vancomycin/vancocin & $50-500 \mathrm{ug}$ & 15 \\
Gentamicin/garamycin & $18-4000 \mathrm{ug}$ & 10 \\
Cefoxitin/cefotaxime/cefuroxime & $240-1000 \mathrm{ug}$ & 6 \\
Amphotericin B & $2.5-50 \mathrm{ug}$ & 5 \\
Lincomycin & $120 \mathrm{ug}-300 \mathrm{mg}$ & 3 \\
Penicillin/benzylpenicillin & $30-50 \mathrm{IU}$ & 3 \\
Amikacin & $25-100 \mathrm{ug}$ & 3 \\
Polymyxin B & $200-1000 \mathrm{ug}$ & 3 \\
Piperacillin & $50-500 \mathrm{ug}$ & 2 \\
Colistin & $200 \mathrm{ug} / 1000 \mathrm{IU}$ & 2 \\
Streptomycin & $50 \mathrm{ug}$ & 2 \\
Tobramycin & $50 \mathrm{ug}$ & 1 \\
Cotrimoxazole & $50 \mathrm{ug}$ & 1 \\
Fluconazole & $500 \mathrm{mg}$ & 1 \\
Flucloxacillin & $200 \mathrm{ug}$ & 1 \\
Fungizone & $250 \mathrm{ug}$ & 1 \\
Fungoral & $100 \mathrm{ug}$ & 1 \\
Imipenem & $200 \mathrm{ug}$ & 1 \\
\hline
\end{tabular}

TABLE 5: Types of incubation media used for decontamination of allografts.

\begin{tabular}{lcc}
\hline Incubation media & Number of HVBs & $\%$ of HVBs \\
\hline $\begin{array}{l}\text { Medium 199 (TC-199/M199) } \\
\text { Roswell Park Memorial Institute }\end{array}$ & 11 & $46 \%$ \\
$\begin{array}{l}\text { Media 1640 (RPMI-1640) } \\
\begin{array}{l}\text { 0.9\% sodium chloride (normal } \\
\text { saline) }\end{array}\end{array}$ & 5 & $21 \%$ \\
$\begin{array}{l}\text { Dulbecco's Modified Eagle's } \\
\text { Medium (DMEM) }\end{array}$ & 2 & $12.5 \%$ \\
$\begin{array}{l}\text { Hanks Balanced Salt Solution } \\
\text { (HBSS) }\end{array}$ & 2 & $8 \%$ \\
Ringers lactate & 1 & $8 \%$ \\
\hline
\end{tabular}

(2) Processing outcome of HVBs:

(i) how many donors and allografts does your bank process annually?

(ii) what proportion of allografts meet release criteria?

(iii) what are the most common reasons allografts fail to meet release criteria?

(iv) what proportion of allografts released for clinical use is implanted?

(v) what are the primary reasons why released allografts are not implanted?

Data was collated from February to April 2011. In this report, the results were summarised and presented as returned, apart for editing for consistency of terminology.
The individual HVBs had been deidentified. The Royal Perth Hospital's Cell and Tissue Therapies WA's Management Committee was consulted prior to implementation of study, and ethics approval was advised to be unnecessary, as the survey was a mere collation of information on the individual HVBs' practices and outcomes, which did not involve the identification of patients.

\section{Results}

3.1. Tissue Processing and Storage Procedures. 24 HVBs participated in this aspect of study. As presented in Tables 1, 2, and 3, both similarities and differences in heart valve processing and storage procedures were identified in the survey. Isotonic solutions or cell culture media were used for valve retrieval, antibiotic decontamination, and cryopreservation. Eleven HVBs (46\%) used Medium 199 (M199), and five (21\%) used Roswell Park Memorial Institute Media 1640 (RPMI1640), while the remainder used Dulbecco's Modified Eagle's Medium (DMEM), sodium chloride (normal saline), Hanks Balanced Salt Solution (HBSS), or Ringer's lactate (Table 5). Twelve of the 18 HVBs (66\%) reported using 9\%-11\% DMSO as cryoprotectant, with the rest using varying concentrations of DMSO $(7.5 \%-20 \%)$ with or without foetal bovine serum or human albumin. In all cases, the media/solutions were purchased as sterile reagents from approved suppliers.

Antibiotic decontamination regimens were found to be exceptionally diverse, both in the antibiotic combinations used (Tables 1-3) and their concentrations (Table 4). The most commonly used antibiotics were vancomycin (15 banks) and gentamicin (10 banks). Seven HVBs also included antifungal drugs in their antibiotic cocktail-five used amphotericin $\mathrm{B}$, one used fluconazole, and another used fungoral.

Most of the European HVBs and half of the North American HVBs surveyed incubated allografts at $4^{\circ} \mathrm{C}$ for 24 hours. In contrast, five of the seven HVBs surveyed from Australasia and South Africa decontaminated their valves at physiological temperature of $37^{\circ} \mathrm{C}$ for $\leq 12$ hours. Overall, 16 HVBs (67\%) conducted bioburden reduction at cold temperatures $\left(1^{\circ} \mathrm{C}-10^{\circ} \mathrm{C}\right)$, with seven HVBs $(29 \%)$ incubating at $33^{\circ} \mathrm{C}-38^{\circ} \mathrm{C}$. Duration of bioburden reduction step varied from 6 to 48 hours, with a majority of the HVBs incubating for 18-26 hours at cold temperatures (12 of 16 banks = $75 \%)$. Those using physiological temperatures $\left(33^{\circ} \mathrm{C}-38^{\circ} \mathrm{C}\right)$ incubated for either $18-26$ hours ( 3 of 7 banks $=43 \%$ ) or $6-12$ hours ( 4 of 7 banks $=57 \%$ ). Two HVBs conducted bioburden reduction at ambient temperature for 24 hours. One HVB decontaminated allografts at either $37^{\circ} \mathrm{C}$ for $6-8$ hours or $4^{\circ} \mathrm{C}$ for 18-24 hours (Table 6).

$92 \%$ of HVBs (22 of 24 banks) used controlled rate freezing to cryopreserve cardiovascular tissues, with the remaining two HVBs using manual freezing in liquid nitrogen vapour phase. All HVBs stored processed allografts at ultralow temperatures $\left(<-135^{\circ} \mathrm{C}\right)$ or in liquid nitrogen vapour phase. Storage duration ranged from 2 to 15 years, with the majority of HVBs (16 of 23 banks $=70 \%$ ) storing released homografts for five years. 
TABLE 6: Incubation temperatures and durations used for decontamination of allografts.

\begin{tabular}{|c|c|c|c|c|}
\hline Incubation temperature (in ${ }^{\circ} \mathrm{C}$ ) & Incubation time (in hours) & Number of HVBs & Number of HVBs & $\%$ of HVBs \\
\hline \multirow{4}{*}{$\begin{array}{l}1-10 \text { (cold temperature, including } \\
\text { at } 4^{\circ} \mathrm{C} \text { ) }\end{array}$} & $6-24$ & 1 & \multirow{4}{*}{16} & \multirow{4}{*}{$67 \%$} \\
\hline & $12-18$ & 2 & & \\
\hline & $18-26$ & $12^{*}$ & & \\
\hline & 48 & 1 & & \\
\hline 21 (ambient temperature) & $18-26$ & 2 & 2 & $8.3 \%$ \\
\hline \multirow{2}{*}{$\begin{array}{l}\text { 33-38 (physiological } \\
\text { temperature) }\end{array}$} & $6-12$ & $4^{*}$ & \multirow[b]{2}{*}{7} & \multirow{2}{*}{$29 \%$} \\
\hline & $18-26$ & 3 & & \\
\hline
\end{tabular}

* Refers to a HVB which decontaminates allografts at either $37^{\circ} \mathrm{C}$ for $6-8$ hours or $4^{\circ} \mathrm{C}$ for $18-24$ hours.

The procedures used for processing, bioburden reduction, cryopreservation, and storage had been validated by all responding HVBs.

\subsection{HVBs' Processing Activities and Outcomes. 23 HVBs} participated in this aspect of study. A summary of the heart valve processing activities and outcomes is presented in Tables 7, 8, and 9 . The annual number of donors and allografts processed by the different HVBs varied extensively both between and within jurisdictions. Donor numbers ranged from 4 to over 3700 , with 8 to 8500 allografts processed annually. Many HVBs in Europe, North America, Australasia, and South Africa have less than 50 donors annually. In contrast, there are two, very large HVBs in North America, which processe allografts from more than 1000 donors each year (Table 10).

On average, $70 \%$ of the processed allografts (range $=$ $39 \%-90 \%$; mean $=69 \%)$ met the HVBs' release criteria. Twenty-one HVBs (21 of 23 banks $=91 \%$ ) reported positive microbiology results as a primary reason for allografts failing to meet release criteria. Ten (10 of 23 banks $=43 \%)$ listed abnormal morphology of tissues, which is defined as presence of calcification, excessive atheroma (particularly in aortic valves), excessive fenestrations, fibrosis, dilatation, and sinus aneurysm, as a reason for product failure. Positive serology results of donor, valve incompetency during testing, technical issues, quality, and donor related findings (e.g., medical contraindication) were also cited as reasons for product failure. One large North American HVB deferred further processing of donor tissues based on low clinical demand of a certain valve type (i.e., aortic valve) and valve sizes (Table 11).

On average, $85 \%$ of allografts meeting release criteria (range $=50 \%-100 \%)$ were implanted. Uncontrollable factors such as low demand for aortic valves, nonvalve allografts, and certain valve sizes were cited as the primary reason for released products not being implanted by 17 HVBs (17 of 23 banks $=74 \%)$. The majority of these valves were discarded due to reaching maximum storage duration. Clinical decision during surgery was also cited as a reason why valves were not implanted. Other factors, which could be monitored and potentially improved upon, include perioperative incidents, such as incorrect valve size delivered to implant hospitals, damage during thawing, and intraoperative contamination of allograft. Four HVBs cited these factors as reasons that prevented implantation of released allografts $(4$ of 23 banks $=$ 17\%) (Table 11).

\section{Discussion}

Based on the information published in 2004, there are 85 HVBs worldwide, with the majority located in Europe, Canada, USA, and Australia. There are only three HVBs in Asia [5]. From the responses collated from 24 of these HVBs located in various jurisdictions, it is obvious that global harmonisation of heart valve manufacturing procedures has not been achieved. This is not surprising, as each country has different microbial, environmental, regulatory, and logistical challenges to overcome. Despite so, the more routine processing aspects appeared to be relatively standardised. These included (1) the use of sterile culture media for all processing steps, with the majority of banks using either M199 or RPMI1640 , (2) the use of DMSO as a cryoprotectant, with $72 \%$ of the banks utilising this reagent at a concentration of $9 \%-$ $11 \%$, (3) bioburden reduction by antibiotic disinfection, (4) controlled rate freezing for cryopreservation of allografts, and (5) storage of allografts at ultralow temperatures of below $-135^{\circ} \mathrm{C}$ or in liquid nitrogen vapour phase.

However, in terms of procedural details, numerous differences were also identified. They included (1) type of sterile culture media used for processing, (2) antibiotics combination, (3) temperature and duration used for bioburden reduction, (4) concentration of DMSO used for cryopreservation, and (5) storage duration for released homografts. These differences in processes, which in some cases had been patented by the individual HVBs, had been validated.

Antibiotic cocktails used for bioburden reduction were diverse in terms of the number, combination, and concentrations of antibiotics used. Vancomycin and gentamicin were the most commonly used antibiotics, with approximately $80 \%$ of HVBs using one or both of these antibiotics. It is noteworthy that some HVBs were found to prefer first-generation antibiotics, such as penicillin and streptomycin, whereas others chose to use newer, broader spectrum antimicrobials, such as vancomycin and gentamicin. The decision to retain the antibiotics cocktail is probably because the effectiveness of these antibiotics had been validated by the HVBs and no protocol change was warranted. However, as continuous improvement in tissue manufacturing is encouraged, it is 
TABLE 7: Summary of heart valve outcomes for HVBs in Europe.

\begin{tabular}{|c|c|c|c|c|c|}
\hline Bank & $\begin{array}{l}\text { Number of } \\
\text { donors/number of } \\
\text { grafts processed } \\
\text { annually (Average) }\end{array}$ & $\begin{array}{l}\text { Proportion of } \\
\text { products meeting } \\
\text { release criteria }\end{array}$ & Reasons for product failure & $\begin{array}{l}\text { Proportion of } \\
\text { released products } \\
\text { implanted }\end{array}$ & $\begin{array}{l}\text { Reasons released } \\
\text { products are not implanted }\end{array}$ \\
\hline E1 & $\begin{array}{l}45 \text { donors } \\
75 \text { valves }\end{array}$ & $\sim 79 \%$ & $\begin{array}{l}\text { (1) Abnormal morphology of } \\
\text { graft } \\
\text { (2) Positive microbiological } \\
\text { results of graft } \\
\text { (3) Positive serology results of } \\
\text { donor }\end{array}$ & $99.5 \%$ & Decision during surgery \\
\hline E2 & $\begin{array}{l}25 \text { donors } \\
40 \text { valves }\end{array}$ & $\sim 70 \%$ & $\begin{array}{l}\text { (1) Failure in valve } \\
\text { competency } \\
\text { (2) Positive microbiological } \\
\text { results of graft } \\
\text { (3) Technical issues }\end{array}$ & $95 \%$ & Decision during surgery \\
\hline E3 & 97 grafts & $\sim 50 \%$ & $\begin{array}{l}\text { Positive microbiological } \\
\text { results }\end{array}$ & $95 \%$ & $\begin{array}{l}\text { (1) Size demands for valves } \\
\text { (2) Low demand for type of } \\
\text { valve }\end{array}$ \\
\hline E4 & $\begin{array}{l}72 \text { donors } \\
80 \text { valves } \\
130 \text { patches }\end{array}$ & $90 \%$ & $\begin{array}{l}\text { (1) Failure in valve } \\
\text { competency (primarily aortic } \\
\text { valves) } \\
\text { (2) Positive microbiological } \\
\text { results of graft }\end{array}$ & $98 \%$ & $\begin{array}{l}\text { Decision during surgery, } \\
\text { cancellation of surgery }\end{array}$ \\
\hline E5 & $\begin{array}{l}4 \text { donors } \\
8 \text { valves }\end{array}$ & $\sim 69 \%$ & $\begin{array}{l}\text { (1) Positive microbiological } \\
\text { results of graft } \\
\text { (2) Positive serology results of } \\
\text { donor }\end{array}$ & $100 \%$ & NA \\
\hline E6 & $\begin{array}{l}35 \text { donors } \\
30 \text { valves }\end{array}$ & $\sim 70 \%$ & $\begin{array}{l}\text { Positive microbiological } \\
\text { results of graft }\end{array}$ & $95 \%$ & $\begin{array}{l}\text { Low demand for aortic } \\
\text { valves }\end{array}$ \\
\hline E7 & $\begin{array}{l}20-30 \text { donors } \\
50 \text { valves }\end{array}$ & 90\% & $\begin{array}{l}\text { (1) Positive microbiological } \\
\text { results of graft } \\
\text { (2) Technical issues }\end{array}$ & $60 \%$ & $\begin{array}{l}\text { Size demand for valves-a } \\
\text { congenital cardiac centre } \\
\text { only }\end{array}$ \\
\hline E8 & $\begin{array}{l}40-50 \text { donors } \\
80 \text { valves }\end{array}$ & $\sim 80 \%$ & $\begin{array}{l}\text { Positive microbiological } \\
\text { results of graft }\end{array}$ & $95 \%$ & $\begin{array}{l}\text { (1) Size demand for valves } \\
\text { (2) Beyond maximum } \\
\text { storage duration of patch } \\
\text { graft }\end{array}$ \\
\hline E9 & $\begin{array}{l}300 \text { donors } \\
400 \text { valves }\end{array}$ & $\sim 50 \%$ & $\begin{array}{l}\text { (1) Abnormal morphology of } \\
\text { graft } \\
\text { (2) Positive microbiological } \\
\text { results of graft } \\
\text { (3) Technical issues }\end{array}$ & $\begin{array}{l}85 \%(100 \% \text { for } \\
\text { pulmonary valves } \\
\text { and arterial } \\
\text { allografts) }\end{array}$ & $\begin{array}{l}\text { (1) Aortic valve size } \\
\text { (2) Low demand for aortic } \\
\text { valves } \\
\text { (3) Decision during surgery } \\
\text { (4) Damage of graft during } \\
\text { thawing }\end{array}$ \\
\hline E10 & $\begin{array}{l}100 \text { donors } \\
250 \text { grafts }\end{array}$ & $\sim 68 \%$ & $\begin{array}{l}\text { Abnormal morphology of } \\
\text { graft }\end{array}$ & $65 \%$ & Size demand for valves \\
\hline E11 & $\begin{array}{l}217 \text { donors } \\
380 \text { valves }\end{array}$ & $\sim 78 \%$ & $\begin{array}{l}\text { (1) Abnormal morphology of } \\
\text { graft } \\
\text { (2) Positive microbiological } \\
\text { results of graft }\end{array}$ & $84 \%$ & $\begin{array}{l}\text { (1) Size demand for valves } \\
\text { (2) Low demand for aortic } \\
\text { valves }\end{array}$ \\
\hline
\end{tabular}

important that HVBs routinely review their antibiotic regimens, concentrations, and incubation conditions, to ensure optimal product quality, function, and safety.

The incubation temperature used for bioburden reduction also varied. Interestingly, there appeared to be a regional preference for different tissue incubation temperatures. This trend had previously been reported by Parker. In his study, he found that most tissue banks in Europe and North America treated allografts with antibiotics at $4^{\circ} \mathrm{C}$, whereas banks in
Australia conducted antibiotics decontamination step at $37^{\circ} \mathrm{C}$ [6]. Our survey confirmed these findings, with most banks in Europe and North America incubating recovered donor tissues at $1^{\circ} \mathrm{C}-10^{\circ} \mathrm{C}$ for $18-24$ hours and the majority of banks in Australasia incubating at $35^{\circ} \mathrm{C}-37^{\circ} \mathrm{C}$ for $6-12$ hours. One Australasian $\mathrm{HVB}$ had validated both temperatures $\left(4^{\circ} \mathrm{C}\right.$ and $37^{\circ} \mathrm{C}$ ) for varying durations (18-24 hours and 6-8 hours, resp.) to ensure that processing could be completed within the required time frame. 
TABLE 8: Summary of heart valve outcomes for HVBs in North America.

\begin{tabular}{|c|c|c|c|c|c|}
\hline Bank & $\begin{array}{c}\text { Number of } \\
\text { donors/no. of } \\
\text { grafts processed } \\
\text { annually (Average) }\end{array}$ & $\begin{array}{l}\text { Proportion of } \\
\text { products meeting } \\
\text { release criteria }\end{array}$ & Reasons for product failure & $\begin{array}{l}\text { Proportion of released } \\
\text { products implanted }\end{array}$ & $\begin{array}{l}\text { Reasons released products } \\
\text { not implanted }\end{array}$ \\
\hline N2 & $\begin{array}{l}55 \text { donors } \\
70 \text { valves }\end{array}$ & $\sim 70 \%$ & $\begin{array}{l}\text { (1) Abnormal morphology } \\
\text { of graft } \\
\text { (2) Positive serology results } \\
\text { of donor } \\
\text { (3) Positive microbiological } \\
\text { results of graft } \\
\text { (4) Donor related }\end{array}$ & $\begin{array}{l}100 \% \text { for pulmonary } \\
\text { valves } \\
20 \% \text { for aortic valves }\end{array}$ & $\begin{array}{l}\text { Low demand for aortic } \\
\text { valves }\end{array}$ \\
\hline N3 & $\begin{array}{l}42 \text { donors } \\
68 \text { grafts }\end{array}$ & $\sim 78 \%$ & $\begin{array}{l}\text { Positive microbiological } \\
\text { results of graft }\end{array}$ & $\begin{array}{l}32 \% \text { of grafts were } \\
\text { confirmed to be } \\
\text { implanted, } \\
16.5 \% \text { of grafts were } \\
\text { exported } \\
\end{array}$ & $\begin{array}{l}\text { Low demand for aortic } \\
\text { valves }\end{array}$ \\
\hline N4 & 2400 grafts & $\sim 60 \%$ & $\begin{array}{l}\text { (1) Positive microbiological } \\
\text { results of graft } \\
\text { (2) Quality/donor related }\end{array}$ & $80 \%$ & $\begin{array}{l}\text { (1) Size demand for valves } \\
\text { (2) Nonvalve grafts are not } \\
\text { in demand }\end{array}$ \\
\hline N5 & $\begin{array}{c}3700 \text { donors } \\
8500 \text { grafts } \\
\text { (including valves, } \\
\text { patches, } \\
\text { descending } \\
\text { thoracic aorta and } \\
\text { pericardium } \\
\text { patches) }\end{array}$ & $\sim 39 \%$ & $\begin{array}{l}\text { (1) Deferred due to } \\
\text { size/type of graft } \\
\text { (2) Graft } \\
\text { attribute/abnormal } \\
\text { morphology of graft } \\
\text { (3) Positive microbiological } \\
\text { results of graft }\end{array}$ & $99 \%$ & $\begin{array}{l}\text { Beyond maximum storage } \\
\text { duration }\end{array}$ \\
\hline N6 & $\begin{array}{c}34 \text { donors } \\
57 \text { grafts (valves, } \\
\text { conduits, and } \\
\text { pulmonary } \\
\text { hemiarteries) }\end{array}$ & \multicolumn{2}{|c|}{ No response provided } & $53 \%$ & $\begin{array}{l}\text { (1) Intraoperative } \\
\text { contamination of graft } \\
\text { (2) Incorrect size of graft } \\
\text { (3) Beyond maximum } \\
\text { storage duration }\end{array}$ \\
\hline
\end{tabular}

Differences in duration and temperature of bioburden reduction step, as well as the combination and concentration of antibiotics used by individual HVBs, can be attributed to a number of factors. Firstly, the fact that each procedure had been validated, in some cases patented, and shown to be effective in removing detectable microbial contamination from the allografts, justifies the retention of both antibiotic cocktail and incubation procedure for each HVB. In addition, differences in endemic microorganisms sensitive to different antibiotics are also valid reasons for maintaining these procedural differences between different HVBs.

Although different antibiotics function optimally within specific temperature ranges and possess varying degrees of stability, maximal antibiotic activity is generally achieved at a physiological temperature of $37^{\circ} \mathrm{C}$, when most microorganisms are actively replicating $[7,8]$. A comprehensive study conducted in 2010 by Germain et al. demonstrated that exposure to antibiotics at $37^{\circ} \mathrm{C}$ resulted in a rapid decrease in the number of colony-forming units of 12 bacterial strains [8]. In addition, the results of a recent study by Fan et al. suggested that the lower decontamination success rate observed when bioburden reduction step was conducted at $4^{\circ} \mathrm{C}$ was because the micro-organisms were not actively replicating at this temperature. This was particularly relevant for slow-growing organisms, such as the common skin contaminant, Propionibacterium acnes [9]. However, it is recognised that disinfecting tissues at this lower temperature has the advantages of reducing bacterial proliferation, as well as preventing warm ischemia damage to the tissue $[9,10]$. To minimise potential ischemic damage, most HVBs that incubated allografts at $37^{\circ} \mathrm{C}$ used an incubation time of $\leq 12$ hours [7].

It is noteworthy that the antifungal drug, amphotericin B, was included in the antibiotic cocktail of some HVBs, when its usage had been discontinued in others $[7,11]$. Deleterious effects of amphotericin B on human tissue viability and cell damage were reported by various studies $[12,13]$. However, the necessity to preserve cell viability for optimal graft function remained controversial. There is clinical evidence that viable valves at the time of cryopreservation had a lower level of structural deterioration than that of nonviable valves. Such valves were more likely to retain thicker leaflets and fewer perforations, as compared with nonviable valves [14]. Conversely, studies have reported the loss of cell viability after cryopreservation and thawing, suggesting that viable cells might not contribute to valve function and durability in situ [15]. It has even been suggested that the presence of viable cells in the graft may actually increase immunogenicity in 
TABLE 9: Summary table of heart valve outcomes for HVBs in Australasia and South Africa.

\begin{tabular}{|c|c|c|c|c|c|}
\hline Bank & $\begin{array}{l}\text { Number of } \\
\text { donors/number of } \\
\text { grafts processed } \\
\text { annually (average) }\end{array}$ & $\begin{array}{l}\text { Proportion of } \\
\text { products meeting } \\
\text { release criteria }\end{array}$ & $\begin{array}{l}\text { Reasons for } \\
\text { product failure }\end{array}$ & $\begin{array}{l}\text { Proportion of } \\
\text { released products } \\
\text { implanted }\end{array}$ & $\begin{array}{l}\text { Reasons released } \\
\text { products are not implanted }\end{array}$ \\
\hline $\mathrm{A} 1$ & $\begin{array}{l}12 \text { donors } \\
16 \text { valves }\end{array}$ & $\sim 75 \%$ & $\begin{array}{l}\text { (1) Positive microbiological } \\
\text { results of graft } \\
\text { (2) Abnormal morphology } \\
\text { of graft }\end{array}$ & $77 \%$ & $\begin{array}{l}\text { (1) Size demand for aortic } \\
\text { valves } \\
\text { (2) Low demand for aortic } \\
\text { valves }\end{array}$ \\
\hline $\mathrm{A} 2$ & $\begin{array}{l}27 \text { donors } \\
77 \text { grafts }\end{array}$ & $\sim 50 \%$ & $\begin{array}{l}\text { (1) Positive microbiological } \\
\text { results of graft } \\
\text { (2) Donor related (medical } \\
\text { contradiction) }\end{array}$ & $90-100 \%$ & $\begin{array}{l}\text { Size demand for aortic } \\
\text { valves }\end{array}$ \\
\hline A3 & $\begin{array}{l}80 \text { donors } \\
232 \text { grafts } \\
\text { (118 valves and } \\
114 \text { patches) }\end{array}$ & $\sim 70 \%$ & $\begin{array}{l}\text { (1) Positive microbiological } \\
\text { results of graft } \\
\text { (2) Positive serology results } \\
\text { of donor }\end{array}$ & $\begin{array}{c}100 \% \text { for } \\
\text { pulmonary valves; } \\
\text { majority for aortic } \\
\text { valves; } \\
100 \% \text { for patches }\end{array}$ & $\begin{array}{l}\text { (1) Size demand for aortic } \\
\text { valves } \\
\text { (2) Beyond maximum } \\
\text { storage duration }\end{array}$ \\
\hline A4 & $\begin{array}{l}20 \text { donors } \\
36 \text { valves }\end{array}$ & $\sim 83 \%$ & $\begin{array}{l}\text { (1) Positive microbiological } \\
\text { results of graft } \\
\text { (2) Abnormal morphology }\end{array}$ & $74 \%$ & $\begin{array}{l}\text { Low demand for aortic } \\
\text { valves }\end{array}$ \\
\hline A5 & $\begin{array}{l}24 \text { donors } \\
34 \text { valves }\end{array}$ & $90 \%$ & $\begin{array}{l}\text { Positive microbiological } \\
\text { results of graft }\end{array}$ & $\sim 100 \%$ & $\begin{array}{l}\text { (1) Quality of graft } \\
\text { (2) Beyond maximum } \\
\text { storage duration }\end{array}$ \\
\hline A6 & $\begin{array}{l}29 \text { donors } \\
49 \text { valves }\end{array}$ & $\sim 71 \%$ & $\begin{array}{l}\text { (1) Positive microbiological } \\
\text { results of graft } \\
\text { (2) Abnormal morphology } \\
\text { (3) Failure in valve } \\
\text { competency }\end{array}$ & $91 \%$ & $\begin{array}{l}\text { Nonvalve grafts are not in } \\
\text { demand }\end{array}$ \\
\hline A7 & $\begin{array}{l}75 \text { donors } \\
98 \text { valves }\end{array}$ & $\sim 61 \%$ & $\begin{array}{l}\text { (1) Positive serology results } \\
\text { of donor } \\
\text { (2) Positive microbiological } \\
\text { results of graft } \\
\text { (3) Abnormal morphology } \\
\text { of graft }\end{array}$ & $\sim 80 \%$ & Size demand for valves \\
\hline
\end{tabular}

TABLE 10: Number of donors processed by HVBs, according to geographical region.

\begin{tabular}{|c|c|c|c|c|}
\hline Number of donors & Europe & North America & Australasia and South Africa & Total \\
\hline$<50$ & 7 & 2 & 5 & 14 \\
\hline $51-100$ & 2 & 1 & 2 & 5 \\
\hline $101-1000$ & 2 & 0 & 0 & 2 \\
\hline$>1000$ & 0 & 2 & 0 & 2 \\
\hline
\end{tabular}

TABLE 11: Reasons for product failure and why released products were not implanted.

\begin{tabular}{|c|c|c|c|}
\hline Reasons for product failure & Number of HVBs & Reasons why released products were not implanted & Number of $\mathrm{HVBs}$ \\
\hline During evaluation of tissue and processing & & Uncontrollable factors & \\
\hline Abnormal morphology & 10 & Size demands for valves & 11 \\
\hline Failure in valve competency & 3 & Aortic valve/nonvalve products not in demand & 10 \\
\hline Technical issues & 3 & Beyond maximum storage duration & 5 \\
\hline Deferred due to size/type of graft & 1 & Decision during surgery & 4 \\
\hline After tissue processing & & Factors that can be improved on & \\
\hline Positive microbiological results of graft & 21 & Damage of graft during thawing & 1 \\
\hline Positive serology results of donor & 5 & Intraoperative contamination of graft & 1 \\
\hline \multirow{2}{*}{ Quality/donor related } & \multirow{2}{*}{3} & Incorrect size of graft & 1 \\
\hline & & Quality of graft & 1 \\
\hline
\end{tabular}


situ $[16,17]$. Nonetheless, the presence of viable cells precryopreservation is recognised as a useful indicator of optimal tissue preservation [14].

Despite the extensive variation in antibiotic regimens, reported decontamination success rates remain comparable at between $60 \%$ and $70 \%$ for different HVBs [9]. This confirmed the results of our survey where the mean proportion of allografts meeting clinical release criteria was found to be $69 \%$. However, when comparing the proportion of valves meeting release criteria achieved by individual HVBs, the results were actually quite disparate (range $=39 \%-90 \%$ ). This finding appeared to reflect the stage at which tissue exclusion criteria were applied. Some HVBs might have processed all donors' tissues prior to application of tissue exclusion criteria, while others ensured that the criteria were met prior to processing. One large North American HVB chose not to process valves based on low clinical demand for the valve type (i.e., aortic valve) and/or size, which reduced the proportion of their products released for implant to only $39 \%$.

Storage duration for released valves ranged from 2 to 15 years, with the majority of HVBs $(\sim 70 \%)$ storing the allografts for 5 years. Some groups advocated that allografts should be stored for $\leq 5$ years. However, this limit was based on convention rather than a validated study. Mirabet et al. concluded that any significant loss of cell viability in tissues stored in liquid nitrogen for $\leq 13$ years was due to freezing and thawing protocols rather than the storage duration [18].

Almost all HVBs cited "positive microbiological culture of graft" as one of the primary reasons for allografts failing to meet release criteria. Several factors, such as the recovery site environment, sequence of tissue recovery, aseptic recovery and processing techniques, and suboptimal effectiveness of antibiotics used for decontamination, could contribute to this result. Fan et al. reported a significantly higher initial contamination rate of arterial tissues compared to heart tissues, which was ascribed to the less sterile state of the abdominal compartment where the arteries were recovered, especially if trauma was involved [9]. The Prince Charles Hospital also reported high contamination rates when they initiated valve retrieval from multiorgan donors. A review of procedures found contamination to be more common if previous retrieval teams had perforated the bowel or the heart had been removed with instruments used to retrieve other tissues. A higher incidence of contamination has also been reported for valves recovered in an open mortuary area due to the reduced air quality of the mortuary environment [7]. Given the numerous sources for potential contamination, effective aseptic practices at all stages of tissue recovery and processing are essential to minimise the risk of tissue contamination and loss of products.

Over the last thirty years, there has been a significant change in clinical demand for allografts from aortic valves to pulmonary valves. The reasons for this change include an increase in paediatric cardiac surgery, the adoption of the Ross procedure, and improved durability of aortic porcine valves $[19,20]$. Various reports also associated the use of aortic valves with more rapid failure than pulmonary valves $[21,22]$. The reduced clinical demand for aortic valves, along with low demand for certain valve sizes, were cited as the primary reasons why released valves were not implanted by the majority of HVBs. Together, these valves represented the majority of grafts discarded due to maximum storage duration attained. Other graft types, such as patches, face a similar challenge due to the ready availability of cost-effective animal-sourced patches.

There are several limitations to this study. Firstly, there were only $24 \mathrm{HVBs}$, which participated in this survey. This means that the processing practices and outcomes of many other HVBs remain unknown. Secondly, although all HVBs performed formal validation on major processes, the test methodologies used were different. Thirdly, there is a lack of patient-related parameters, which are more accurate measurements to the quality of final products and, ultimately, the success of transplanted allografts. Ideally, parameters such as early leaflet failure, iatrogenic infection, and other perioperative adverse events of patients, due to processing variables and thawing protocols, should be reviewed. While beyond the scope of this paper, a separate study should be performed to address these issues and potentially identify practical solutions.

Although the findings of this survey suggested that procedures currently in use by the individual HVBs were validated, in consideration of the wide variation in percentage of allografts fulfilling release requirements (range $=39 \%-90 \%$ ), some purportedly validated protocols may not be performing as optimally as others. This seems to present an opportunity for improvement in the heart valve banking industry. As underperforming protocols will incur substantial losses to HVBs, all efforts to improve HVBs' processing activities and recipient outcomes should be encouraged. Although "global harmonisation" is a worthy goal, it is doubtful if this can be achieved in the heart valve banking industry for a number of reasons, which include patented processes, organisational restrictions, and environmental differences. However, regular reviews of important outcomes as cited in this paper and monitoring of adverse patient events should encourage comparison and improvements in the HVBs' processes.

\section{Acknowledgment}

The authors are greatly appreciative of all the heart valve banks who participated in this survey and generously shared their own banks' practices.

\section{References}

[1] M. E. Staab, R. A. Nishimura, J. A. Dearani, and T. A. Orszulak, "Aortic valve homografis in adults: a clinical perspective," Mayo Clinic Proceedings, vol. 73, no. 3, pp. 231-238, 1998.

[2] K. G. M. Brockbank and D. J. B. Siler, "Aseptic and antiseptic treatment of donated and living engineered organs and tissues," in Disinfection, Sterilization, and Preservation, S. B. Seymour, Ed., pp. 1011-1022, Lippincott Williams \& Wilkins, Philadelphia, $\mathrm{Pa}$, USA, 5th edition, 2001.

[3] W. L. Heng, C. H. Lim, B. H. Tan et al., "From penicillinstreptomycin to amikacin-vancomycin: antibiotic decontamination of cardiovascular homografts in singapore," PLoS One, vol. 7, no. 12, Article ID e51605, 2012. 
[4] D. Fehily, S. A. Brubaker, J. N. Kearney, and L. Wolfinbarger Jr., "The role of professional standards in the context of regulations," in Tissue and Cell Processing: An Essential Guide, D. Fehily, Ed., Wiley-Blackwell, 2012.

[5] S. Verghese, P. Padmaja, B. Sindhu, S. J. Elizabeth, N. Lesley, and K. M. Cherian, "Homograft valve bank: our experience in valve banking," Indian Heart Journal, vol. 56, no. 4, pp. 299-306, 2004.

[6] R. Parker, "An international survey of allograft banks," in Cardiac Valve Allograft. Science and Practice, M. H. Yacoub, Ed., pp. 5-9, Springer, New York, NY, USA, 1997.

[7] K. Gall, S. Smith, C. Willmette, M. Wong, and M. O'Brien, "Allograft heart valve sterilization: a six-year in-depth analysis of a twenty-five-year experience with low-dose antibiotics," Journal of Thoracic and Cardiovascular Surgery, vol. 110, no. 3, pp. 680-687, 1995.

[8] M. Germain, L. Thibault, A. Jacques, J. Tremblay, and R. Bourgeois, "Heart valve allograft decontamination with antibiotics: impact of the temperature of incubation on efficacy," Cell and Tissue Banking, vol. 11, no. 2, pp. 197-204, 2010.

[9] Y.-D. Fan, B. Van Hoeck, V. Holovska, and R. Jashari, "Evaluation of decontamination process of heart valve and artery tissues in European Homograft Bank (EHB): a retrospective study of 1,055 cases," Cell and Tissue Banking, vol. 13, no. 2, pp. 297-304, 2012.

[10] R. Parker, "Banking of heart valves," in Essentials of Tissue Banking, G. Galea, Ed., pp. 69-80, Springer, New York, NY, USA, 1st edition, 2010.

[11] M. F. O’Brien, D. C. McGiffin, E. G. Stafford et al., "Allograft aortic valve replacement: long-term comparative clinical analysis of the viable cryopreserved and antibiotic $4^{\circ} \mathrm{C}$ stored valves," Journal of Cardiac Surgery, vol. 6, no. 4, supplement, pp. 534543, 1991.

[12] R. Villalba, P. Alonso, J. Manuel Villalba, L. F. Rioja, and J. Luis Gómez Villagrán, "The effect of amphotericin B on the viability of cryopreserved human skin," Cryobiology, vol. 32, no. 4, pp. 314-317, 1995.

[13] B. Wegner, P. Baer, S. Gauer, G. Oremek, I. A. Hauser, and H. Geiger, "Caspofungin is less nephrotoxic than amphotericin B in vitro and predominantly damages distal renal tubular cells," Nephrology Dialysis Transplantation, vol. 20, no. 10, pp. 20712079, 2005.

[14] K. L. Gall, S. E. Smith, C. A. Willmette, and M. F. O'Brien, "Allograft heart valve viability and valve-processing variables," Annals of Thoracic Surgery, vol. 65, no. 4, pp. 1032-1038, 1998.

[15] L. C. Armiger, "Viability studies of human valves prepared for use as allografts," Annals of Thoracic Surgery, vol. 60, no. 2, supplement, pp. S118-S121, 1995.

[16] F. Hoekstra, M. Witvliet, C. Knoop et al., "Donor-specific antihuman leukocyte antigen class I antibodies after implantation of cardiac valve allografts," Journal of Heart and Lung Transplantation, vol. 16, no. 5, pp. 570-572, 1997.

[17] L. C. Armiger, "Postimplantation leaflet cellularity of valve allografts: are donor cells beneficial or detrimental?" Annals of Thoracic Surgery, vol. 66, no. 6, supplement, pp. S233-S235, 1998.

[18] V. Mirabet, C. Carda, P. Solves et al., "Long-term storage in liquid nitrogen does not affect cell viability in cardiac valve allografts," Cryobiology, vol. 57, no. 2, pp. 113-121, 2008.

[19] D. N. Ross, "Homograft replacement of the aortic valve," The Lancet, vol. 280, no. 7254, p. 487, 1962.
[20] K. G. M. Brockbank, J. F. Carpenter, and P. E. Dawson, "Effects of storage temperature on viable bioprosthetic heart valves," Cryobiology, vol. 29, no. 5, pp. 537-542, 1992.

[21] J. S. Tweddell, A. N. Pelech, P. C. Frommelt et al., "Factors affecting longer of homograft valves used in right ventricular outflow tract reconstruction for congenital heart disease," Circulation, vol. 102, no. 19, supplement 3, pp. III130-III135, 2000.

[22] E. Troost, B. Meyns, W. Daenen et al., "Homograft survival after tetralogy of Fallot repair: determinants of accelerated homograft degeneration," European Heart Journal, vol. 28, no. 20, pp. 2503-2509, 2007. 


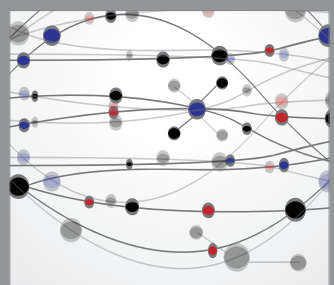

The Scientific World Journal
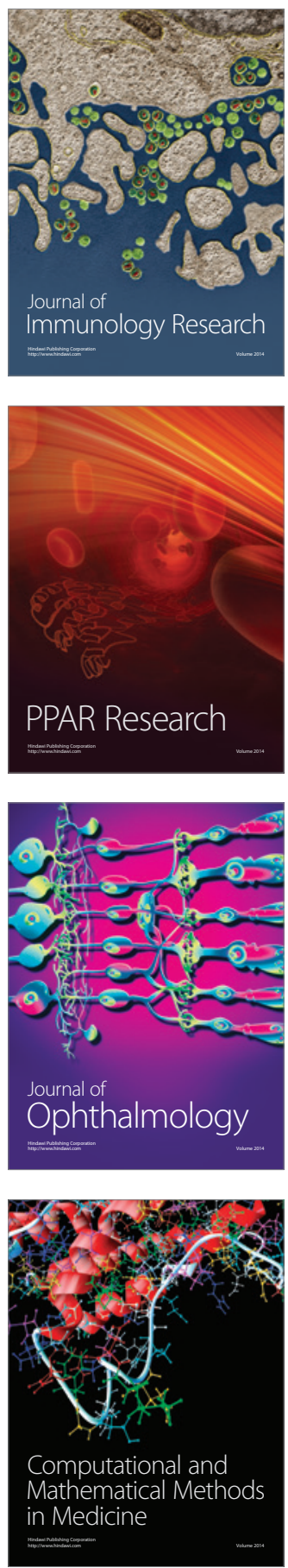

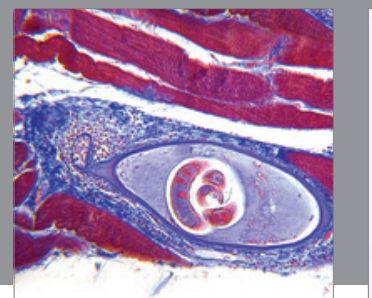

Gastroenterology

Research and Practice
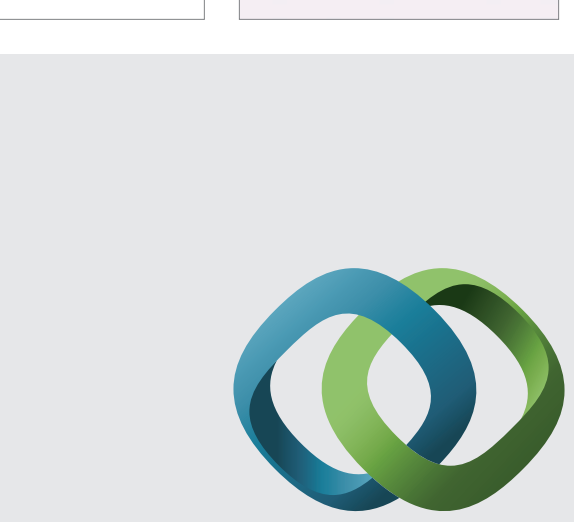

\section{Hindawi}

Submit your manuscripts at

http://www.hindawi.com
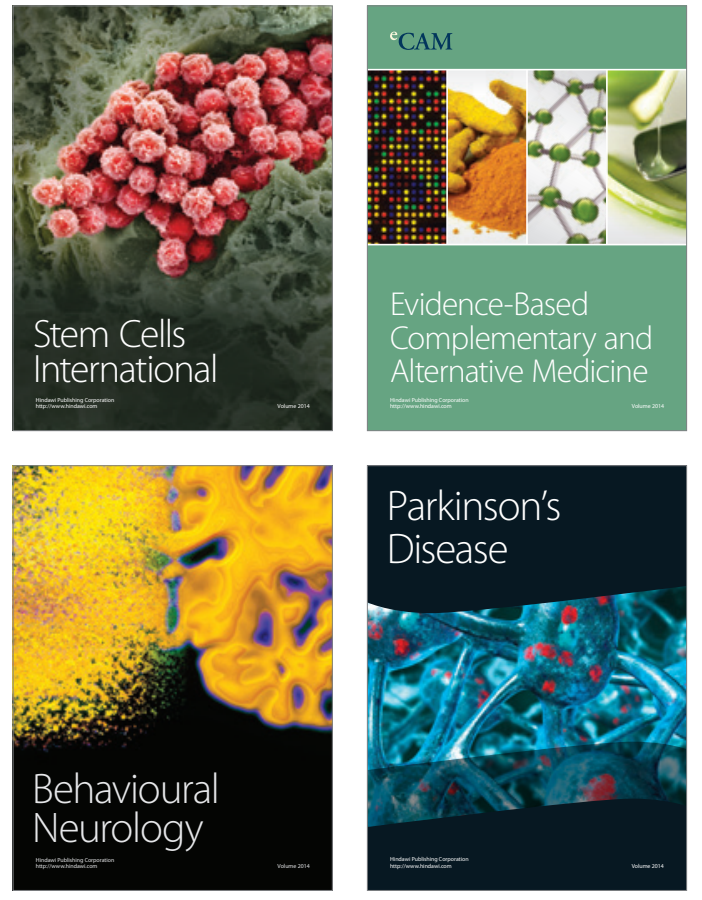
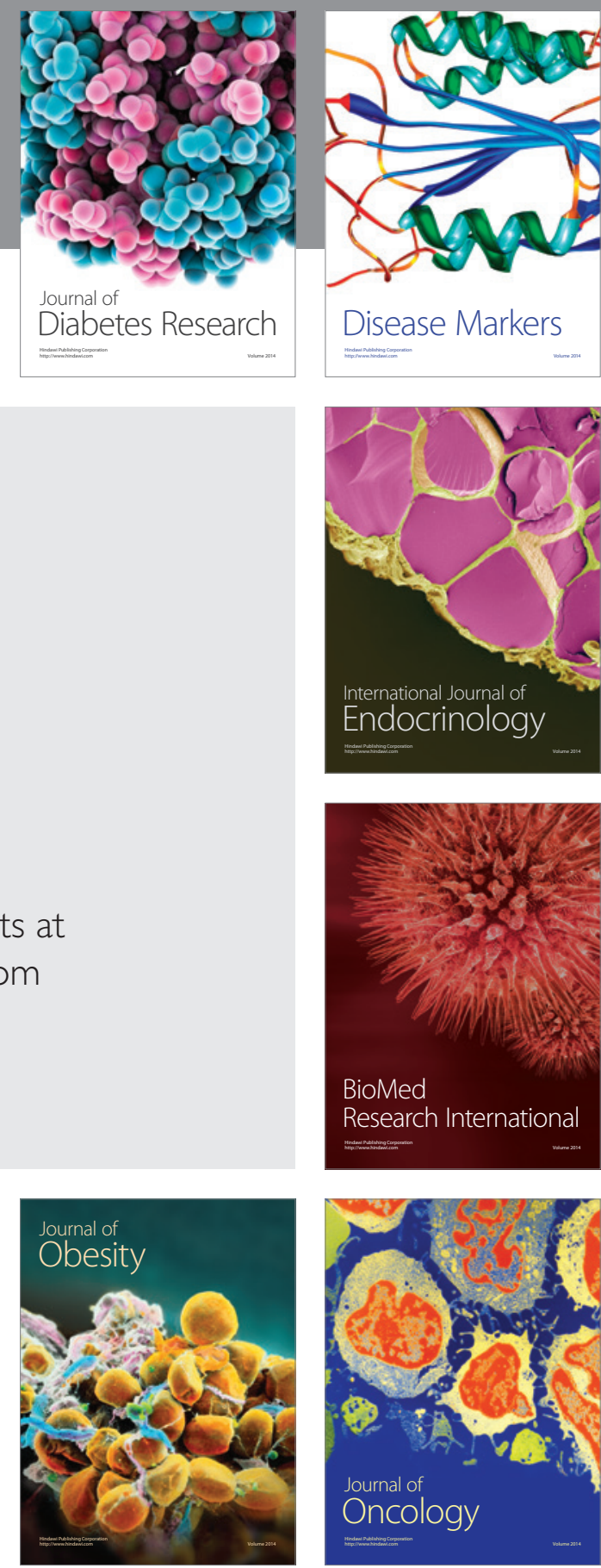

Disease Markers
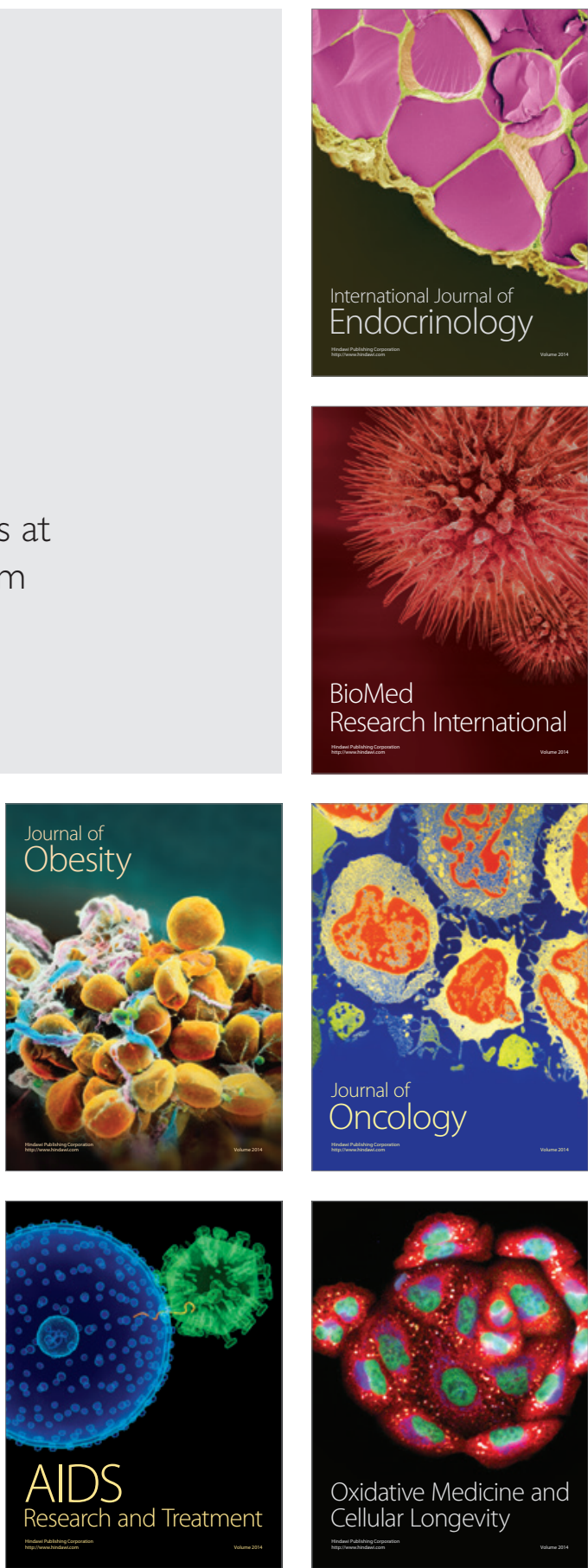